\title{
Islamic Values in the Practice of Natural Conservation in Indonesia
}

\author{
Sukarsono \\ Biology Education Department, University of Muhammadiyah Malang \\ sukarsono_umm@yahoo.com
}

\begin{abstract}
Uncontrollable environmental destructions pose some questions on the development paradigm adopted so far. Islam as the source of values for its followers is expected to contribute some thoughts in trying to solve environmental problems practically. This research was conducted in two places in which the figures of Islam have been considered successful in adopting Islamic values approach to conservation in Indonesia. A qualitative phenomenological approach with the existing model was employed in this present study. The data were collected by using the techniques of in-depth interviews, participation observations, and documentary studies. The trustworthiness of the findings was made through credibility, dependability and confirmability techniques. The data were analyzed by arranging and categorizing the data and then by looking for the patterns or themes to understand their meanings. The research results showed that the figures of Islam, the doers of the conservation, possessed and applied Islamic values in their conservation. The values are the basic values and instrumental values relating one another. The basic values of conservation found are human values as the caliphs in the earth. Meanwhile, the instrumental values are knowledge, shadaqah jariyah, anfa', diligence, itsar, and the parents' mandate.
\end{abstract}

Keywords: basic value, instrumental value, Islam, natural conservation.

\section{INTRODUCTION}

The process of the natural destruction happening from year to year is more uncontrollable and more difficult to solve due to some multidimensional factors. The root of the problems is the adopted capitalistic and secular development paradigm (Witoszek, 2011; Tucker \& John Grim, 2009, 2010; Nokel, 2009).

The disappointment with the processes and the results of the development considered to fail and to be unsustainable (ICEE, 2007) causes various criticisms and suggestions from prominent figures in ethics to take into account religion in each development process. A religion is the source of value that may promote people's feelings to do something (Kempton et al, 1995; Yusdani, 2010; Tucker \& John Grim, 2009, 2010); Rozaqi (2005); AlQaradhawi (2002); Maliki (2011); and Rachman (2011).

Rozaki A (2005) explains that at present religion, it is not merely looked at as a set of teachings of values, a normative dogma, but also as an object of study. Religion is studied to know how the divine matter is historized in the daily exegesis practices and social actions.

Therefore, religion may be observed and analyzed in order to make religious behaviors seen and felt. The problem is that the religion tradition in general has not provided a practical manual to respond contemporary issues arising in the development process, such as the problem of climate changes, water scarcity, and the like (Tucker, M.E and John Grim. 2009, Jessani, \& Graham Reid, 2011).

Al-Qaradhawi (2002) and Rahman B,M (2011) state that the study of ethics on the relation of Islam and the nature should be explored. A religion should become the source of values in the whole aspects of the development, including the environment. But in fact, up to now, studies of the values of religions in the process of environmental development are still rare.

\section{LITERATURE REVIEW}

Theories on pro-environmental human behaviors state the importance of the existence of values, motivation and orientation (Kollmuss, A \& J, Agyeman. 2010; Stern et al, 1993; Burgess et al. 1998; Ajzen, I. \& Fishbein, M. 1980; Hines et al, 1986). Schwartz (1977) proposes basic values in either the individual or in the community. The basic value is the basic motivation of the individual's or community's attitudes and behaviors.

Winarno (2007) suggests that spiritual value is the one dealing with human existence and being influenced by transcendental dimensions of which the making meaning levels depend on each one's self-experience and self-awareness. These basic values are general and usually universal in nature (Ekosusilo, 2003), so that the consistency across cultures will be different (Schwartz, 1977). In life reality, the community needs detailed descriptions on the principles of the basic values to make them cover varied and have wide possibilities in human actions (Mulyana, 2004).

Aoyagi et al (2003) suggests the relation between the basic values and the people who follow them and the instrumental values. Mulyana (2002) states that instrumental values happen through social and cultural processes. As an expert in interpreting the Koran, Shihab (1996) gives deep, detailed, and logic explanations about human values related to the natural conservation. Overall, the values centre in the Koran as the life compass of the ummah of Islam. 
The way of classifying the values on the basis of the personal and social aspects, according to Mulyana (2002) occurs as a consequence of one's general tendency to stick in certain values because he or she sees the benefits from the realization of the values. Individual values appear as a form of adaptation in life experiences. The adaptation may be in the form of the reparation (selection) of good values to take and bad ones to omit (Ayogi, 2003).

Individual or personal values or life styles are also introduced by Robbins (1991) stating that personal values show a multilevel arrangement from the lowest (developed without any awareness) to the highest.

Aoyagi et al (2003) and Schwartz (1977) state that the people's social values will have a high priority if they are related to their interest in self-concept. Social values will be stronger if they are given a positive response.

Various research results suggest that one's pronatural behaviors are influenced by his knowledge, his values, and attitudes (Kollmuss, 2010; Stern et al, 1993; Ajzen, 1980).

\section{METHOD}

In this present research, a qualitative phenomenological approach with the existing model (Winarno, 2007) was employed. The selected approach also emphasized the naturalistic condition, field work, and where the researchers were the main instrument. The research was focused on the visible phenomena and the foregrounding symptoms in line with the researchers' subjective understanding (Lincoln \& Guba, 1985).

The subject and location of this research were predetermined, namely the prominent figures of Islam, the doers of the natural conservation, and receivers of awards in the field of environment either at the national or international level.

The data collection were made through the techniques of in-depth interviews, participation observations and document studies (Lincoln \& Guba, 1985; Moleong, 2005). The data on the values were collected via in depth-interviews, using procedures as Kempton et al (1995); and Dietz et al (2005) did. The manual of the interviews was made on the basis of Torkar et al (2011). The thrustworthiness of the data was made through credibility or validity, dependability, and confirmability). The activities of the data analysis are based on Miles and Huberman's (Linacre, J.M, 1995) and Winarno's theory (2007), which is through the process of arranging and categorizing the data and looking for patterns or themes in order to understand their meanings.

\section{RESULTS}

\section{Natural Conservation Basic Value}

The basic values are possessed and developed by the prominent figures of Islam, The doers of the conservation are human values as the caliphs in the earth. Their values are from the life orientation of the ummah of Islam namely the Holy Al Qur'an (Koran). In the conservation activities, the prominent figures of Islam possess the value of caliph to do three main things: improving the supporting power of the environment, maintaining and making use of the nature wisely and sustainably. The basic values are made as the main reference to do some ritual obligations to have a direct relation to God and to meet daily needs.

Shihab (1996a) explains that the term caliph in the Holy Koran is anyone given some powers to manage either a wide or limited area. Improving the environmental supporting power is one of the forms of area management. If a land has been alive, the people will get some benefits from it for their lives (AlQaradhawi, Y. 2002; Abdillah, M. 2002). The opinion is shared by many writers stating that the duty of human beings as the caliph is in making the use of the nature, and they are not allowed to destroy the environment, above all, to let their wild desires exploit the nature that disobeys the orientation as the caliphs (Husaini, 1980; Miri, 2007; Arieff. \& Farahwahida, 2012; Akhtar, MR. 1996)).

\section{The Instrumental Values of Islam in the Natural Conservation}

The instrumental values were developed by the doers to commit the basic values they possessed. The values are unique operational possessed by or became the motivation factor of the prominent figures or a group of prominent figures to undergo their tasks as the caliphs.

The instrumental values found in the research are individual and social in nature. The values are knowledge shadaqah jariyah, anfa', diligence, itsar, and parents' mandate.

Knowledge value; it is a very important value in the natural conservation activities. All figures state that their behaviors are based on their knowledge. The knowledge considered to give the most significant influence is from trainings and experiences. Moreover, the knowledge is also obtained from the books they study in pesantrens.

Shadaqah Jariyah Value; this deals with the firm belief that there would be sustainable rewards for their moral conduct from God for every conservation activity they do. The rewards will always flow although the doers pass away. This happens because conservation activities (like planting trees) will give sustainable benefits to the people and the environment although those planting the trees die. One of the principles in Islam is believed to say something about the conservation: "al 'amalu al muta'adli afdhalu min amali al kashir. It means every work that is continuously done (muta'adli) is more prominent than that which is not sustainably done. There is a proverb saying that giving a hook is better than giving a fish.

Anfa' Value; it means that the existence of something due to some behaviors will result in more, wider, and deeper or higher values. The resulting values of the conservation are more complex and not single. For example, guava trees have fruits that can be sold, and its leaves contain oxygen, serve as shelters, and absorb $\mathrm{CO} 2$. Moreover the guava trees may absorb rain water 
into the soil, produce compost for worms, and the like. The Anf' value is taken from a hadith from Moslem Stories, stating: "Khoiru an naas anfa'u hum li an naas", meaning the best human beings among you are those who may give the most benefits to others. Conservation will give more benefits to the environment.

Diligence Value; this value has been trained since they were santris. It is a determining factor to the success of the conservation. Diligently, the doers are able to obtain various achievements, rewards and trusts from the society including foreign institutions. The doers' diligence may be seen from the amount of time spent for conservation activities. Some prominent figures have done conservation activities for more than 20 years continuously, either through education or daily conservation practices.

Itsar (Altruist) Value; this value grows and develops in the individual figures of Islam, the doers of the conservation. The itsar value may be clearly seen from the santris and people's behaviors and the information where the prominent figures give priorities for the interest of the people and the environment over those of themselves and their families. This value not only becomes a part of the figures themselves but also has been trained to the santris to make them possess the same value when they should do something for the interest of their people and their environment.

Parent's Mandate Value; parents have a very important position and value in encouraging every conservation behavior. Conservation actions are not only based on the consideration of committing religion teachings, but are also caused by the parents' mandate to their offspring to conserve better. Respecting the parents, including implementing all their good instructions will result in rewards and goodness for their descendants. Therefore, obeying parents and doing conservation are the two acts that God loves most, and these will result in glory and high rewards from God.

\section{REFERENCES}

[1] Abdillah, Mujiono. 2010. The Islmic EcoReligion (Concept and implementation of Islamic Ecospiritual). Eco-spirituality through Green Development. Universitas Islam Indonesia. Yogyakarta. 9 Desember 2010.

[2] Ajzen, I. and Fishbein, M. 1980 Understanding Attitudes and Predicting Social Behavior Englewood Cliffs, NJ, Prentice Hall.

[3] Akhtar, M Ramzan. 1996. Towards An Islamic Approach For Environmental Balance. Islamic Economic Studies. 3 (2): 57-76.

[4] Al-Qaradhawi, Yusuf. 2002. Islam Agama Ramah Lingkungan. Jakarta. Pustaka Al-Kautsar.

[5] Aoyagi-Usui, Vinken and Kuribayashi. 2003. Proenvironmental Attitudes and Behaviors: An International Comparison. Human Ecology Review, 10 (01): 23-31.

[6] Arieff, S.R, Selamat H, dan Farahwahida, M.Y. 2012. An Introduction to Qur'anic Principles on
Water Environment Management. 1st International Conference on Multiple Government in Islam, Environmental Development and Conservation, Johor, Malaysia, UTM. 2-3 November 2012.

[7] Burgess, J., Harrison, C. and Filius, P. 1998. Environmental communication and the cultural politics of environmental citizenship, Environment and Planning. I (30): 1445-1460.

[8] Ekosusilo,M. 2003. Winning School-Based Value; Multi Case studies in SMA I, SMA Regina Pacis and Al-Islam High School I Surakarta. Surakarta. Univet Bantara Press.

[9] Jessani, Nasreen, dan Graham Reid. 2003. Knowledge Management. Research Matters project, collaboration of International Development Research centre (IDRC) and the Swiss Agency for Development and Cooperation (SDC). [Online] From: www.resarch-matters.net. [Acessed on 23 November 2012]

[10] Hines, J.M., Hungerford, H.R. \& Tomera, A.N. (1986-87). Analysis and synthesis of research on responsible pro-environmental behavior: a metaanalysis, The Journal of Environmental Education, 18 (2): 1-8.

[11] Husaini, S.W. Ahmad. 1980. Islamic Environmental Systems Engineering: A Systems Study of Environmental Engineering, and the Law, Politics, Education, Economics, and Sociology of Science and Culture of Islam. London. Macmillan Press.

[12] ICEE. 2007. The Ahmedaba Declaration 2007: A Call to Action; Education for Life; Life through Education. 4th International Conference on Environmental Education. United Nation. Ahmedabad. India.

[13] Kempton W, Boster and JS, Hartley JA. 1995. Environmental Values in American Culture Cambridge. MA: MIT.

[14] Kollmuss Anja and Julian Agyeman. 2010. Mind the Gap: Why do People Act Environmentally and What are the Barriers to promote environmental behavior?. Environmental education Research Journal. 8 (3): 239-260.

[15] Lincoln YS \& Guba, 1985. Naturalistic Inquiry. Beverly Hill: CA:SAGE Publictions Inc.

[16] Maliki, Zainal. 2011. Reconstruction of Islamic Thought for Environmental Protection. Build "The Ecological Conscience" Approach Philosophy and Religion. Malang. Indonesia 23 Oct 2011.

[17] Moleong, Lexy, J. 2005. Kualitatif Methodology. Bandung. Remaja Rosda Karya..

[18] Mulyana. 2004. The Articulation of Value Education. Bandung. Alfabeta.

[19] Nokel. Sigrid, 2009, Islam, Natrue and Sustainability.

htt://id.qantara.de/ebcom/show_article.php/ _c769/_nr-11/i.html, Diakses tanggal 29 Desember 2010. 
[20] Rachman Budi Munawar, 2011, Human, Nature and the Environment for life: Build "The Ecological Conscience" Approach Philosophy and Religion. Malang. Indonesia 23 Oct 2011.

[21] Rozaqi, A, 2005, Research on Religion in Cultual Persfective, paper for Studium Research on Religion in Cultutral Persfective, Fakultas Adab UIN Sunan Kalijaga Yogyakarta.

[22] Schwartz, Shallom.H. 1977. Normative in•uences on altruism, in: L. Berkowitz (Ed.) Advances in Experimental Social Psychology. New York, Academic Press.

[23] Shihab, Mohammad Quraish. 1996. Making AlQur'an Down to Earth to the Living of Communities (13th Ed) Bandung. Mizan

[24] Dietz. Thomas, Amy Fizgerald, and Rachael Shown. 2005. Environmental Values. Environmental Resources. I (30): 335-372

[25] Torkar Gregor, Barbara Zimmermann dan Tomas Willebrand. 2011. Qualitative Interviews in Human Dimensions Studies about Nature Conservation. Sprejeto, Varstvo Narave Journal, 25 (2011): 39-52.

[26] Tucker, M.E and John Grim, 2010. World Religion, the Earth Chrater and Sustainability. [Online]

From: http://fore.research.yale.edu/publicatioons/project s/tuckerec3. pdf. .[Acessed 18 February 2011].
[27] Stern, P.S., Dietz, T. \& Karlof, L. 1993. Values orientation, gender, and environmental concern, Environment and Behavior, 25(3): 322-348.

[28] Linacre, J.M, 1995, Learning from Qualitative Data Analysis. [Online] From: http://www.rasch. org/rmt/ rmt9la.htm. [Acessed on 12 September 2011]

[29] Miri, Seyyed Mohsen. 2007. Principles and Phylosophy of Mulla Shadra as a Basic Ethics and Cosmology of Environment. [Online] From http://ahmadsamantho. wordpress.com/2007/12/07/prinsip-ekologi-islammulla-shadra/. [Acessed on 12 September 2011]

[30] Winarno, Agung. 2007. Internalization of Entrpreneurships Values: Phenomenologic Approach Research in SMK Negeri 3 Malang. Dissertation of Departement of Economic Education. Post Graduate, Malang University.

[31] Witoszek, N. 2011. Globalization and Sustainability: A Humanist Agenda. Journal for the Study of Religion, Nature and Culture, Ecotheology 11 (3): 268-281

[32] Yusdani, 2010. Eco-Spritual in Several Persfective. Religion and Environment. Indonesia Islamic University. Yogyakarta. 11 March 2011. 